\title{
ROLE OF TRAFFIC IN THE DEVELOPMENT OF SERBIAN- HUNGARIAN FRONTIER REGION
}

\section{A KÖZLEKEDÉS SZEREPE A SZERB-MAGYAR HATÁRRÉGIÓ FEJLÖDÉSÉBEN}

\author{
Éva Szügyi, Éva Szügyi, Ph.D. hallgató, okl. közgazdász \\ A Pécsi Regionális Politika és Gazdaságtan Doktori Iskola hallgatója, Szabadkai Regionális \\ Tudományi Társaság kutatója \\ Address: $\quad$ Szerbia, 24430 Ada, Djure Djakovica utca 169/c. \\ Phone: $\quad 00$ 8163-8592-451 \\ E-mail: $\quad$ eva.szugyi@yahoo.com
}

György Sefcsich, Prof. Dr.

Gépészmérnök, környezettechnológiai szakmérnök, a müszaki tudományok doktora, nyugalmazott címzetes müegyetemi tanár

Address: $\quad$ Szerbia, 24000 Subotica, 4. jula utca. 19/a

Phone: $\quad+38124780500$

E-mail: $\quad$ sefcsich@gmail.com 


\title{
ROLE OF TRAFFIC IN THE DEVELOPMENT OF SERBIAN- HUNGARIAN FRONTIER REGION
}

\section{A KÖZLEKEDÉS SZEREPE A SZERB-MAGYAR HATÁRRÉGIÓ FEJLŐDÉSÉBEN}

\author{
Key words: \\ frontier region, traffic, infrastructure, development, trade and passenger traffic
}

\begin{abstract}
:
The character of the frontier region, available natural power sources, economy structure inherited from the past and the one that has formed recently, cultural and historical past show more and more powerfully the common interests of the homogeneous region that has been agressivly devided by a border as well as the forced competitive state between each other.

Parts of the region on both sides of the frontier practically possess identical natural and human resources and are forced to appear on the same target market, with nearly identical offer of goods and sevices. If they go on with their uncoordinated market policy and fail to harmonize their development ideas they will not be able to avoid the disadvantageous consequences of unsparing competition in their own region. The only rational opportunity for the settlements in the region is to avoid the grave failors of inner competition and their transformation into a comparative advantage in order to make the deviding frontier be a well working, uniting innovative and economy combining spindle.
\end{abstract}

Relation and mutual dependence is strong in the frontier region and so are the highly important infrastructure corridors, transcontinental size traffic and trade processes as well as their servicing logistic background systems.

Practically the examined local and regional plans and strategies during the research consider the natural endowments and esteem them as comparative advantages. They stress the importance of positive economical effects due to transit corridors that pass through the region. Conditions get naturally formed for high energy centers, intensive development zone along them but they do not even mention - the danger of,tunnel effect" more and more frequently felt recently - the fact that their advantages succseed in a more modest way while the negative effects (serious environment load and environment damages, the increse of relative development differences among the regions along corridors and outskirts that might lead to a dangerous cutting down of outskirts) become more and more palpable.

The analyses of inside and transit passenger traffic and trade in the frontier region affirm - even in the more developed world - the well known and stressed occurence that road traffic is prodigal energy consumer and seriously burdons environment (because of unlimited mobility requirement of passengers and advantages of controlled trade) has a causelessly high (nearly $75 \%$ ) quota - compared with railway and water traffic.

\section{Kulcsszavak:}

határtérség, közlekedés, infrastruktúra, fejlesztés, áru- és személyforgalom

\section{Kivonat:}

A határrégió jellege, rendelkezésére álló természeti erőforrásai, a múltból örökölt és a közelmúltban kialakult gazdaságszerkezete, valamint kulturális és történelmi múltja, egyre erőteljesebben mutatnak rá az államhatárral eröszakosan megosztott, azonban egységes térség közös érdekeire, kényszerü egymás közötti versenytársi helyzetére. A határtérségnek az államhatár két oldalára került térségrészei gyakorlatilag azonos természeti és 
emberi erőforrásokkal rendelkeznek és ugyanazokon a cél-piacokon kényszerülnek fellépni, szinte azonos termék- és szolgáltatás-kínálattal. Amennyiben, tovább folytatva koordinálatlan piacpolitikájukat, idejében nem hangolják össze fejlesztési elképzeléseiket, kényszerüen számolniuk kell a saját térségükkel folytatott kíméletlen konkurenciaharc súlyosan hátrányos következményeivel. A térség települései számára az egyetlen racionális lehetőség, a belső konkurencia súlyos buktatóinak elkerülésére és azok komparatív előnnyé történő transzformációjára, hogy a szétválasztó államhatárt jól müködő, egységesítő innovációs és gazdaságegyesítő tengellyé formálja.

A határrégió esetében erőteljes az összetartozás és a kölcsönös egymásrautaltság, a nagyjelentőségủ infrastruktúra-korridorok, transzkontinentális méretü közlekedési és áruforgalmi folyamatok, valamint az azokat kiszolgáló logisztikai háttérrendszerek vonatkozásában. Gyakorlatilag a kutatás során górcső alá vett regionális és lokális fejlesztési tervek és stratégiák mindegyike számba veszi és komparatív előnyként értékeli ezeket az adottságokat. Mindenekelőtt a térségen áthaladó nagy tranzitkorridorokból eredő pozitív gazdasági hatásokat emelik ki. Azok mentén ugyanis természetszerüen teremtődnek meg a fejlesztés-intenzív zónák és magas-energiájú központok képződésének feltételei. Ugyanakkor meg sem említik -az elmúlt időszakban sajnos egyre gyakrabban érezhető,,,alagúteffektus“ veszélyeit,- vagyis, hogy azok vitathatatlan elönyei egyre szerényebb mértékben érvényesülnek, negatív hatásaik (súlyos környezetterhelés és károsodás, valamint a korridorok mentén kialakuló fejlődőképesebb térségek és a távolabbi perifériák közötti viszonylagos fejlettségi különbségek tovább növekszenek, akár súlyosan leépítve a fejletlenebb perifériákat) viszont egyre kitapinthatóbbá válnak.

A határrégió belső és tranzitjellegü utas- és áruforgalmának elemzései is megerősítették - a fejlett világban is régóta ismert és hangsúlyozott jelenséget, hogy a pazarló energiafogyasztású és a környezetet súlyosan terhelő közúti forgalomnak (az utazók korlátozások nélküli mobilitás igénye és a kísért/irányítható áruforgalom előnyei miatt) indokolatlanul magas (közel 75\%-os!) részesedése van - a vasúti és a vízi közlekedéssel szemben. 


\section{BEVEZETŐ}

A „határrégió” egy közigazgatásilag nehezen, csupán körvonalazva értékelhetö, államhatárral megosztott, de történelmi, földrajzi, gazdasági és kulturális szempontból organikus egységet képező (határ) térség. Természeti adottságai, erőforrásai, gazdasági szerkezete és kultúrtörténeti múltja, a nyugat-balkáni térség (és azon belül Szerbia) EUcsatlakozásának viszonylatában is igen intenzíven veti fel a két csonka határtérség megkerülhetetlen egymásrautaltságának, kényszerü versenyhelyzetének a kérdését. Mindkét térség gyakorlatilag azonos természeti erőforrásokkal és piacképes termékekkel, szolgáltatásokkal tud fellépni ugyanazokon a célpiacokon. Amennyiben (még idejekorán) nem hangolja össze fejlesztési elképzeléseit, és nem koordinálja fellépését - óhatatlanul hátrányos (vagy hátrányos feltételeket teremtő) versenyhelyzetbe kerül(het) önmagával.

A határ kétségkívül a társadalomtudományok nagyrésze által, mintegy térképszerüen elképzelt tárgy - egy adott népcsoport - „szélén” helyezkedik el és a társadalomtudományok jó másfél évszázados hagyománya egyértelműen arra tanít bennünket, hogy arra figyeljünk, ami a határokon „belül” található.

A modern társadalmak empirikus létének kereteit az állam jelöli ki és tartja össze. Ez viszont a határok kérdésén áll vagy bukik, hiszen a határok meghúzásával és fenntartásával, illetve az azokon keresztüli áramlások ellenőrzésével, szabályozásával, megvámolásával és szubvencionálásával, kulturális, mozgalmi és adminisztratív eszközök általi bátorításával és korlátozásával való szüntelen elfoglaltság az államok kiemelt jelentőségü tevékenysége.

Határtérség alatt azt a határ menti területet értjük, amelynek életére, gazdasági-társadalmi folyamataira jelentős befolyást gyakorol az államhatár léte. Hansen (1983) definíciója még egy olyan korban született, amikor az európai határok többé-kevésbé elválasztó jellegüek voltak. Napjainkban mindenképpen ki kell emelnünk azt a tényt, hogy a határtérség kiterjedését már nem (csak) maga az államhatár, hanem az elválasztott határ menti területek térszerkezeti jellegzetességei, a város- és közlekedési hálózatok határon átnyúló kapcsolódásai, valamint a határ két oldalának eltérő gazdasági-társadalmi jellemzői szabályozzák. Ezek alakítják ki azokat a határon átnyúló lakossági és gazdasági mozgásokat, amelyek a nemzetállami tér határ-menti területeit olyan különlegessé teszik. Napjainkban és térségünkben tehát azt tekinthetjük határ-menti térségnek, amelynek mindennapi életét alapvetően befolyásolják a szomszédos határtérséggel fenntartott interakciók. A térbeli határokkal foglalkozó irodalom egyre többször utal a gyakorlati élet 
azon tényére, hogy a régiók (itt a különböző államokhoz tartozó térségek) közötti éles elhatárolás ma már a múlté, és egyre inkább a rendszerek közötti átmeneti jelleggel bíró övezetek kialakulását figyelhetjük meg (Fleischer 2001; Novotny 2007). Valójában a két definíció együtt érvényes, hiszen továbbra sem negligálhatjuk a határ térszerkezet-formáló szerepét, még akkor sem, ha a schengeni belső határok esetében az államhatár fizikai korlátozó szerepe megszünt.

Az, hogy egy adott terület az államhatár mellett fekszik önmagában nem jelent szükségszerűen hátrányt a társadalmi-gazdasági fejlődésre, sőt bizonyos esetekben kifejezetten előnyös is lehet. Trianon óta Magyarországon a határmentiség - kivéve talán a nyugati határszélet - általában elmaradottságot jelentett. Elsősorban azért, mert ezek a határ menti területek kevésbé integrálódtak az ország gazdasági vérkeringésébe, amelynek számos oka lehetett, de elsősorban politikai magyarázatot kell keresnünk. Másrészt a határmentének hosszú éveken keresztül alig volt kapcsolata a szomszédos határon túl lévő valamikor egy országban lévő egységes régióval.

A határok elválasztó szerepe még ma is jobban érvényesül mint az összekötő híd szerep. A szerb-magyar határszakaszon ez az effektus még inkább kifejezésre jut.

\section{KÖZLEKEDÉSI ÉS ÁRUFORGALMI INFRASTRUKTÚRA}

A közlekedés az utóbbi évtizedekben az áru és személyforgalom növekedésével különös jelentőséget nyert. Ez egyrészt a termelésben/logisztikában bekövetkezett struktúra- és technológiaváltással (just in time, revolving stock stb.), másrészt az emberek kényelemigényével magyarázható. A növekvő közlekedésigényekre a kormányok autópályák, közutak építésével reagáltak. A modern termelésirányítási és logisztikai rendszerek a rugalmasabb individualizált személyszállítási és a kísért áruszállítási megoldásokat helyezték előtérbe.

Különösen fontos és hangsúlyos ez az egymásrautaltság a térséget ellátó, azon áthaladó közlekedési infrastruktúra és az azt termelőerővé formáló, utas- és áruforgalmi logisztikai rendszerek esetében, hiszen a (múltból örökölt, illetve újabban létesített) közlekedési infrastruktúra-objektumok és a rajtuk keresztül történő (transz) kontinentális léptékű utas- és áruforgalmak nem befolyásolható tényezők, kényszerüen objektív körülménynek, adottságnak elfogadott, nagytérségi érdekek megvalósításának részeiként jelennek meg.

A tanulmány által vizsgált terület Magyarországon a Délalföld (Bács-Kiskun, Békés és Csongrád megyék) kb. 2/3-át (Szeged, Mórahalom, Kistelek, Kiskunmajsa, Kiskunhalas, 
Jánoshalma, Bácsalmás, Baja községek); ill. Szerbiában/Vajdaságban a Nyugat- és ÉszakBácskai és az Észak-Bánáti Körzetek kb. 2/3-át (Zombor, Apatin, Hódság, Kúla, Szabadka, Topolya, Kishegyes, Magyarkanizsa, Zenta, Ada, Törökkanizsa, Csóka, Nagykikinda községek) fedi le.

Térségünkben a közlekedési infrastruktúra földrajzi, történelmi, politikai és kulturális viszonyok eredményeként, évszázadok folyamán, a mindenkori igényeket, szükségleteket kívánta kielégíteni. Nem lehet vitás, hogy hosszú távon is, a korábbi időszakokban kiépült közlekedési infrastruktúra fogja meghatározni a távolsági személy- és áruforgalom útvonalait és hogy azt a világgazdaság egészét és a világpolitikai erőviszonyokat is döntő mértékben befolyásolni képes, szinte „vis major” típusú adottságként kell kezelnünk.

A (nyugat) európai kontinens Balkán felé vezető foútvonala ugyan a szerb-magyar határrégión halad keresztül, ám ennek jelentősége és az összeurópai közlekedéshálózati rendszerben játszott szerepe túlértékelt, hiszen (elméletileg) lehetséges logisztikai alapfunkciói azt nem igazán indokolják:

- csomóponti (hub-) szerepe mind a földi, mind a légi közlekedésben jelentéktelen,

- $\quad$ kapu (gateway-) szerepe, miután az csupán a Fiume/Koper-Thesszaloniki-Konstanca végpontokra korlátozódik (Balogh, 2010), viszonylag szük a vonzásterülete és az északi-tengeri Range megakikötőinek (Le Havre, Antwerpen, Rotterdam, Amszterdam, Bréma, Hamburg) nyomasztó fölénye miatt csupán harmadrendü a jelentősége. A „Balkán Európa kapuja” megfogalmazás pedig erősen ideiglenes (talán 1-2 évtizedes?) jellegű, és Szerbia remélhetően közeli EU - csatlakozásával gyorsan feloldódó korlátozó feltétel-együttesnek, inkább politikai marketingszólamnak tekinthető,

- és ugyan tranzit-szerepének jelentősége nem vitatható Európa-Kis-Ázsia /KözelKelet viszonylatban, azonban lényegében csak egyetlen (ÉNy-DK irányú) korridorra szorítkozik, melyhez a Kárpát-medencével összekötő É-D és ÉK-DNy irányú, de már csupán másodlagos fontosságú folyosók társulnak (Erdősi, c).

Európa jelenlegi közlekedési hálózata még a modernkori nemzeti érdekek mentén és elkülönülési törekvések hatására alakult ki, sebtében „összefércelt” országos hálózatok aggregátumaként. Ebből az örökségből származik a felerősödő európai integrációs folyamat fejleményekén a Transz - európai Hálózatok (TEN) integrált rendszere (1. sz. ábra), 
melynek legfontosabb általánosan elfogadott - ma már ugyan több tekintetben is vitatható fejlesztési szempontjai, hogy:

- műszaki kialakítása és üzemeltetése egységes irányelvek szerint történjen,

- az országokat/fővárosokat összekötő folyosókra összpontosítson, és

- a nagyteljesítményű környezetbarát eszközöket (villamosított vasút, tenger- és belvízi hajózás) részesítse előnyben.

1. sz.ábra: A Transzeurópai Hálózat (TEN) integrált vonalas infrastruktúra rendszere (nemzeti fővonal-hálózata) a Balkánon (1 - szárazföldi korridorok, 2 - kiemelt fontosságú transz - balkáni útvonal, 3 - dunai vízi út, 4 - nem korridor autópályák)

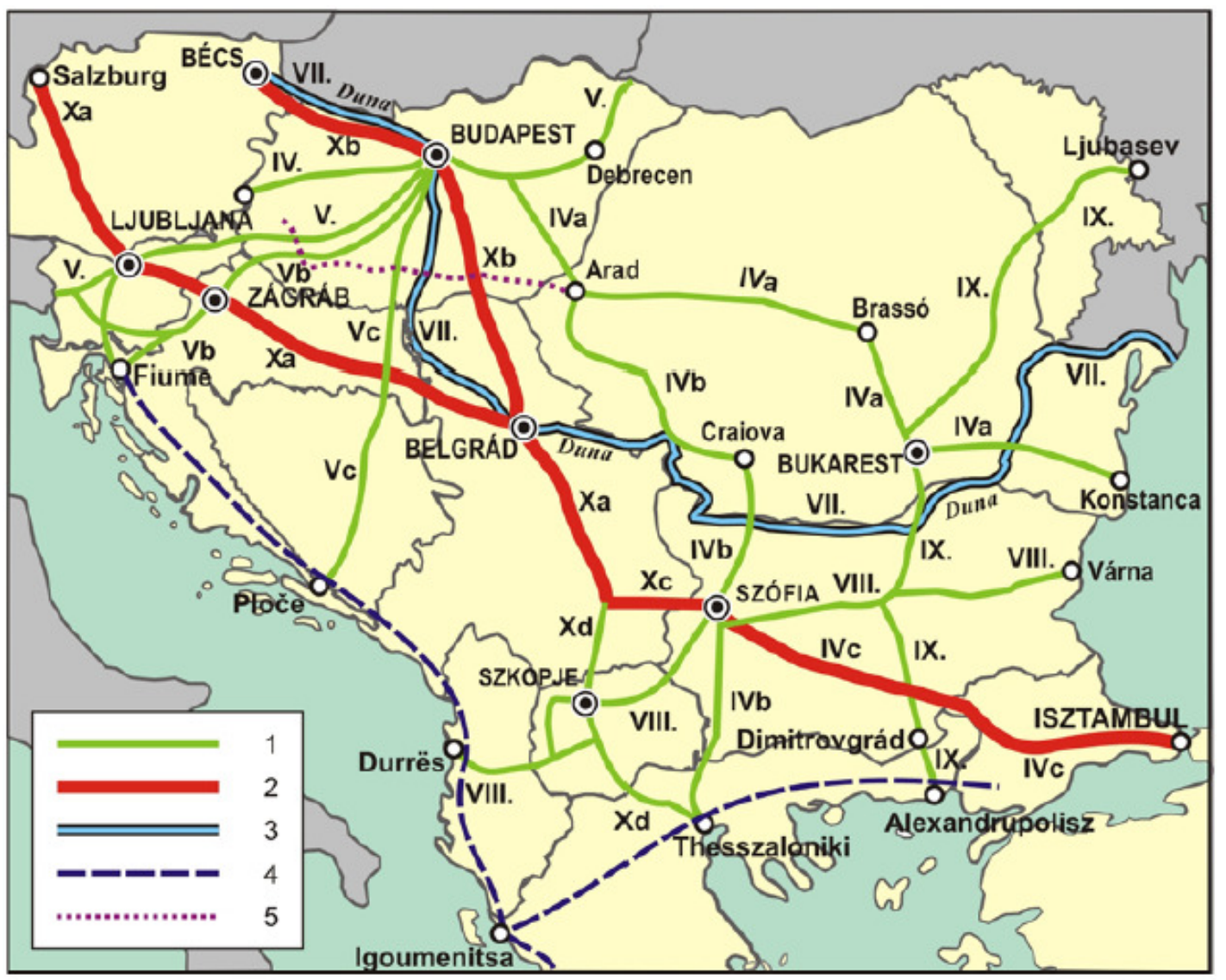

Forrás: Erdősi, F.: A Balkán közlekedése és a politika (prezentáció), 2006.

Jellemző, hogy a TEN korridorok Budapestről sugárnyalábszerüen szétágazva érik el a Balkánt - tehát képletesen és konkrétan is „DK-Európából az út a Kárpát-medencén (Magyarországon) át vezet Nyugat-Európába" - majd a sugaras korridorok a Balkánon tovább osztódnak, ill. más irányokból (Kelet-Európa és Ausztria felől) ide tartókkal egyesülve csomópontokat alkotnak a balkáni fővárosokban és jelentősebb gazdasági központokban (Nagy, 2007). 
A páneurópai X. korridor vasúthálózat képezi Szerbia vasúti közlekedésének gerincét, mivel a háló 25\%-án valósul meg az összes szállítási tevékenység 50\%-a (Erdősi, 2006). A PEN dokumentumok szerint a vasutakat teljes hosszban nagy tengelynyomás hordozására képes, villamosított és túlnyomórészt kétvágányú pályává, a főutakat pedig gyorsforgalmi utakká (túlnyomóan autópályává) tervezték kiépíteni 2010-ig. A jelenlegi kiépítettségi szintben azonban igen nagyok a különbségek, és összességében a balkáni korridorhálózat készültségi foka nem több 30-40\%-nál. Igen jelentős különbség mutatkozik a vasút és autópálya fejlesztési arányok tekintetében a balkáni országok gyakorlata és az EU közlekedéspolitikai direktívái között is. A környezeti és energetikai vonatkozásokra nagy figyelmet fordító Unió a villamosított vasutak és a vízi utak fejlesztését preferálja, viszont (a Nyugat-Európához képest nagyon elmaradott úthálózatra és az ebből eredő gazdasági hátrányokra hivatkozva) a délkelet-európai országok az autópályák és gyorsforgalmi utak építésére összpontosítanak és hangsúlyozottan az uniós források elnyeréséhez kötik a nagyobb mértékü vasútfejlesztéseket. A vasúthálózat mindenütt felújításra, helyenként újjáépítésre szorul (Sefcsich, 2006). E befektetéseknek az összege messze meghaladja a községek erejét. Másrészt viszont, miközben a korridorokon belül éppen a vasutak műszaki színvonalában a legnagyobb a lemaradás, olyan autópályák épülnek, amelyek nem részei az egységesen elfogadott korridor-hálózatnak (Sefcsich, 2007).

A határrégió közgondolkodásában egyre gyakrabban merül fel a jelentős komparatív előnyként értékelt „történelmi”, Arad/Temesvár-Szabadka/Szeged - Zágráb - Fiume/Trieszt (újabban Konstancáig megnyújtott, két egymással versenyző párhuzamos nyomvonalú) kelet-nyugati összekötő „Transz - balkáni korridor” újjáépítésének (mindenekelőtt a Szeged -Szabadka - Zsombolya - Temesvár vasútvonal helyreállításának, ill. a szegedi közúti/vasúti híd újjáépítésének és a Budapest-Szeged tranzitvasútvonal újraaktiválásának) kérdése is. Ennek ugyanis- szerény nagytérségi jelentősége ellenére - igen jelentős térségformáló, integráló hatása lenne éppen a határrégió belső kapcsolatrendszerének talpra állításában és újrafogalmazásában (Sefcsich, 2006).

\section{TELEPÜLÉSFEJLESZTÉSI HATÁSOK}

Ha megvizsgáljuk Észak - Vajdaságot és a Dél - Alföldet, megállapíthatjuk, hogy a trianoni határok meghúzása előtt egy egységes régiót képezett, mind a természetföldrajzi, mind a társadalmi viszonyok kérdésében, de sajnos ezt a homogén területet a határ kettévágta, ami az elmúlt évtizedekben inkább szétválasztotta, mint összekötötte a területet (Huszka, Bakó, 
2007). Mivel a természetnek a határ nem tudott parancsolni ez az elkülönülés különösen a társadalmi viszonyokra volt jellemző, ami megnyilvánult abban, hogy a határnak köszönhetően főleg a második világháború után megszakadt minden fajta kapcsolat a két régió között. Ebből fakadóan nem beszélhetünk egy egységes régióról inkább, mint települések hálózatáról, olyan rendszerről, amelyben a települések csomópontjai a hálózatnak, magát a teret pedig ezek kölcsönhatása tölti ki.

A korridorok terület- és településfejlesztési hatásai erősen ellentmondásosak. Nagyságrendileg javítják ugyan a fővárosok közötti távolsági tranzit-közlekedés feltételeit (kapacitásban, minőségben, utazósebességben), és ezzel magukhoz vonzzák a gazdasági (termelő, kereskedelmi, logisztikai) vállalkozásokat, telephelyeket, ill. végső soron a gazdaságfejlesztés motorját jelentő tőkét és az azt követő képzett, fiatal és ütőképes munkaerőt. Így alakulnak ki a korridorok mentén a GDP-előállításban kiemelkedő területsávok, az autópályák melletti gyorsan fejlődő kontaktzónák, valamint a korridorok metszéspontjaiba települő kimagasló teljesítményt produkáló nagy energiájú központok. Ugyanakkor azonban a korridorok a viszonylag nagy távolságban is érvényesülő elszívó hatásukkal meggyorsítják a távolabbi, periferikus vidéki térségek kiürülését, leépülését - és ezzel végeredményben növelik az egyébként is nyomasztóan nagy területi különbségeket. Ezt az „,alagút-effektust” csak tovább erősíti, hogy térségünkben az infrastruktúra-fejlesztés gyakorlatilag kimerül a korridorok (föként autópályák) építésében és alig jutnak források a mellékutak és a kísérő infrastruktúralétesítmények rendbetételére. Ebből ered, hogy a valóban „alagútként müködő" nagy forgalmú tranzitkorridorok gyakran igen súlyos környezetterhelő negatív hatásai mellett nem érzékelhetők a nyomvonalaik mentén kialakuló fejlődőképes kontaktzónák és területsávok pozitív gazdaságélénkítő hatásai, mert azok - az elégtelen és szegényes infrastruktúra- és gazdasági háttér, továbbá a rövidlátó lokális gazdaságpolitika miatt - nem is képesek kiépülni. Ez a veszély sajnos egyre hangsúlyozottabban van jelen a szerb-magyar határrégión áthaladó közlekedési folyosók mentén.

Jellemző, hogy a kérdéskörrel foglalkozó számos kis- és nagytérségi fejlesztési koncepció és stratégia - mint pl. a nagytérségi szemléletű Dél-alföldi operatív program és a Saobraćaj Efekti integracije Srbije u EU (Közlekedés - Szerbia EU - integrációjának hatásai) c. tanulmány - rendre megállapítja, hogy a régió közlekedés-földrajzi helyzete összességében kedvezőnek mondható, hiszen az országot érintő legfontosabb tranzit-irányú útvonalakon fekszik”. Többnyire (kényszerüen) rámutatnak arra is, hogy „A kedvező földrajzi adottságokkal erős ellentétben van a közlekedési létesítmények szerény kiépítettsége, 
valamint rossz állapota..." A régión belüli és a szomszédos határ menti régiókkal való összeköttetéseket biztosító transzverzális közlekedési kapcsolatok kiépítettsége viszont az észak-dél irányú (fö)közlekedési lehetőségekhez képest alacsony. Nehezíti a helyzetet a dunai, tiszai, valamint a Körösökön található hidak csekély száma, aránytalan elhelyezkedése, nem megfelelő kapacitása. A régión áthaladó fő közlekedési tengelyen kívüli állami közlekedés-fejlesztési beruházások elmaradása - mivel a tengely mentén terjedő tőke, információk, fejlett technológiák dinamizáló hatása kisszámú településre (mindenekelőtt Szegedre és Szabadkára) korlátozódik - a távolabb fekvő térségek relatív hátrányát fokozhatja, periférikus helyzetét konzerválhatja."

\section{KÖZLEKEDÉSI INFRASTRUKTÚRA}

Az autópálya-építések és a vasúti törzshálózati fejlesztések késlekedése erősen rontja a régió gazdasági versenypozícióit, ill. a kedvező logisztikai pozíció kiaknázásának lehetőségeit; másrészt pedig a belső úthálózat és a vasúti mellékvonalak szegényessége szinte ellehetetleníti a térség belső gazdasági integrációját. Ugyanakkor a térségen áthaladó fó közúti gyorsforgalmi korridor „mindenáron” történő továbbépítése mindkét ország számára erőn felüli megterhelést is jelent. A vasúti közlekedés ugyanakkor rövid- és középtávon is súlyos lemaradással és alulfinanszírozottsággal küzd, mind a fóvonalak évtizedek óta elhúzódó és megoldatlan korszerüsítési munkái, mind pedig a súlyosan leépült mellékvonalak felújítása területén. A legnagyobb sebesség $90 \mathrm{~km} / \mathrm{h}$ lenne, ha a vasutak állapota ezt megengedné, viszont helyenként a biztonságos közlekedés csupán a $20 \mathrm{~km} / \mathrm{h}$ sebességet engedélyezi. A megengedett teher 22,5 t, de néhol ez az érték nem haladhatja meg a 16t-t, sőt akár 12t alá is eshet bizonyos szakaszokon. Köztudott, hogy a leépült és elégtelen teljesítményű vasúti összeköttetés erősen korlátozza, gátolja a térség nemzetközi kapcsolatainak kiteljesedését. A vízi közlekedés a határrégió számára - a térségen áthaladó két nagy vízhozamú folyó ellenére - sajnos még középtávon is gyakorlatilag kiaknázhatatlan lehetőség marad - hiszen a bajai Duna-kikötő gyenge infrastruktúra-háttere miatt nehezen elérhető, a Tisza hajózhatósága viszont a zentai kikötő felett már nem biztosított. A folyamhajózás áldatlan helyzetének feloldása csupán egy, a Kárpát-medence egészére kiterjedő, vízvisszatartáson és vízpótláson alapuló, többcélú integrált 
vízgazdálkodási stratégia mentén (árvíz/belvíz-védelem, mederbővítés és folyamhajózás, öntözés, ivóvízbázisok, energetika, környezetvédelem) lesz lehetséges ${ }^{1}$.

Az előnyös közlekedés - földrajzi fekvés ugyan jó alapot képez a kombinált áruszállítási formák terjedéshez, sajnálatos azonban, hogy a kilencvenes évek úttörö kezdeményezéseit (RO-LA Kiskundorozsmán, RO-RO terminál Baján) nem követték további fejlesztések, sőt a meglévő kapacitások kihasználtsága is visszaesést mutat ${ }^{2}$. Pedig a széleskörü szállítási lehetőségek kiváló lehetőségeket képezhetnének a logisztikai bázisok megtelepedésének a régió területén.

A tömegközlekedésben - mind a távolsági és helyközi, mind a helyi járatok viszonylatában a határrégió mindkét oldalán érzékelhető a stagnálás, az egyéni közúti közlekedés előretörése mindenfajta tömegközlekedés rovására. Szervezett közösségi tömegközlekedés csupán Szegeden (kötöttpályás villamos/trolibusz és autóbusz) és Szabadkán (csak autóbusz) müködik, a régió lakosságának csupán töredéke (20-25\%-a) számára elérhető. Ott is hiányzik azonban a helyi és helyközi közösségi közlekedés egységes fejlesztése, ami a fejlődőképesebb regionális központok és az egyre jobban leszakadó perifériák közeledésének, integrációjának egyik fontos feltétele.

A kerékpárút-hálózatok fejlesztése ugyan folyamatos a régió területén, de a már megépült településeken belüli elemek, sem a településeket összekötő szakaszok nem alkotnak egységes térségi, regionális hálózatot.

\section{VEZETÉKES SZÁLLÍTÁSI/SZOLGÁLTATÓI RENDSZEREK ${ }^{3}$}

A határrégió mindkét oldalán intenzív kőolaj- és földgázkitermelés folyik és mindkét ország gyakorlatilag teljes földgázellátása (fogyasztásának közel 90\%-a) a régión áthaladó orosz importból származik, ezen a területen a határrégió két oldala között nem alakult ki közvetlen kommunikáció, hiszen azt mindkét oldalon stratégiai jelentőségű energiapolitikai kérdésként kezelik. A lakosság, az ipari/energetikai létesítmények és közművek földgázellátottsága a határrégió egész területén viszonylag jól kiépített, kielégítőnek tekinthető.

Fontos megjegyezni, hogy az EU és Nyugat-Európa energiaellátását biztosítani hivatott mindhárom tervezett „megkerülő” földgázvezeték (az orosz érdekeltségű Déli Áramlat, az

\footnotetext{
${ }^{1}$ Rečni saobraćaj - Master plan za vodni saobraćaj (Folyami közlekedés - Vízi közlekedési vezérterv), Vlada Republike Srbije, Beograd, 2010.

${ }^{2}$ Dunavska strategija EU i Srbija - Plovidba i prevoz (Az EU Duna-stratégiája - hajózás és áruszállítás), RIS, Belgrád, 2010.

${ }^{3}$ A lokális szintű fejlesztési stratégiák feldolgozása alapján
} 
alternatív betáplálási forrásokra támaszkodó Nabucco és az Azerbajdzsáni cseppfolyósított szállításokra épülő AGRI) nyomvonala - mintegy kényszerü, stratégiai jelentőségü csatlakozási/elosztási (hub) pontot képezve - halad át a szerb-magyar határrégió területén, biztosítva egyúttal mindkét ország és a régió több irányból/forrásból történő energiaellátását.

A teljes határrégió településeinek illetve lakosságának villamos energia ellátottsága igen magas, átlagosan 95\%, a településeken élő lakosság esetében pedig 98\% feletti; a lokális elosztó/ellátó-hálózat műszaki állapota és alkalmassága - számos súlyos hiányossága ellenére - kielégítő (a magyar) vagy még elfogadható (a szerbiai oldalon). A régió északvajdasági térsége számára azonban igen súlyos problémát jelent, hogy áramellátását gyakorlatilag kizárólag az Obrenovac - Újvidék - Szabadka gerinc-távvezeték biztosítja, miután a Szabadka-Szeged (Sándorfalva) távvezeték a Szerbiai Villanygazdaság egyetlen élő kapcsolata az európai elektro - energetikai rendszerrel, és ezért nem képvisel közvetlenül bevethető alternatív ellátási lehetőséget a határrégió számára.

\section{Közlekedés - személy- és áru-forgalom}

A közúti közlekedés kb. 90-éve, a gépjármüipar kialakulásával kezdődött robbanásszerü térnyerésének okai mindenekelőtt a személyes mobilitás és a kísért áruszállítás kényelmi és gazdasági előnyeiben keresendők (Fleischer, 1994). Súlyos környezetkárosító és energiapazarló jellege ellenére a közúti közlekedés ma a fejlett világ személy- és áruforgalmának háromnegyedét mondhatja magáénak, míg a vasúti közlekedés $20 \%$ alá szorult, a belföldi vízi közlekedés pedig (5\% körül) erősen marginalizálódott. Meg kell azonban jegyezni, hogy az egyes országok, térségek szintjén e tekintetben is igen jelentős különbségek tapasztalhatók. A legfrissebb Eurostat jelentés szerint pl. a vasúti szállítás részaránya Svédországban $(36,4 \%)$ és Ausztriában $(34,8 \%)$, még most is jelentős, sőt az USA-ban $40 \%$ feletti, és a belföldi vízi szállítás is pl. Belgium, Németország és Románia esetében 10-15\% körüli, Hollandiában pedig eléri a 33\%-ot!

A vizsgált határrégió közlekedésének és áruforgalmának intenzitása és belső szerkezeti megoszlása sajnos igen nehezen értékelhető, hiszen maga a térség közigazgatásilag is lazán fogalmazható meg csupán, és ezért értelemszerűen a rendelkezésre álló statisztikai adatok/adatbázisok is csak közvetve és feltételesen értelmezhetők.

A határrégióba beérkező és azt elhagyó utas- és áruforgalomról hozzáférhető adatok ugyan sem időben sem mértékegységi értelmezésben nem tekinthetők statisztikailag összevethető 
egzakt és konform adatsoroknak, de nagyságrendi értékrendek felállítására és azokból eredő következtetések levonására mindenképpen alkalmasak (1. sz. táblázat).

1. táblázat: Szállított utasok és áru

\begin{tabular}{|r||r|r|r|r|}
\hline & $\begin{array}{c}\text { Szállított } \\
\text { utasok } \\
(1000)\end{array}$ & $\begin{array}{c}\text { Utaskilom- } \\
\text { éterek } \\
\text { (millióban) }\end{array}$ & $\begin{array}{c}\text { Szállított } \\
\text { áru } \\
(1000 \mathrm{t})\end{array}$ & $\begin{array}{c}\text { Tonna } \\
\text { kilométerek } \\
\text { (millióban) }\end{array}$ \\
\hline \hline 2002 & 97406 & 6124 & 21990 & 4683 \\
\hline 2003 & 91019 & 5950 & 21700 & 4809 \\
\hline 2004 & 89136 & 5883 & 23541 & 5603 \\
\hline 2005 & 89019 & 6754 & 28269 & 6829 \\
\hline 2006 & 92110 & 7416 & 28737 & 7787 \\
\hline 2007 & 84647 & 6538 & 27040 & 8383 \\
\hline 2008 & 86866 & 6747 & 30368 & 7881 \\
\hline 2009 & 86624 & 6227 & 22697 & 5954 \\
\hline
\end{tabular}

Forrás: Opštine u Srbiji, 2010.

Igen fontos tény, hogy a térségbe beérkező, az azt elhagyó, valamint a rajta áthaladó (tranzit) forgalom gyakorlatilag egyetlen észak-déli (fó) korridoron (a TEN Xb Budapest Szeged-Szabadka - Újvidék/Belgrád folyosón) keresztül valósul meg ${ }^{4}$, és a térségen belüli és a szomszédos térségek felé irányuló „,belső” utas- és áruforgalom intenzitása viszonylag marginális jelentőségü (2. sz. ábra).

\footnotetext{
${ }^{4}$ DKMT eurorégió stratégiája, MTA RKK, Alföldi Tudományos Intézet, 1997
} 
2. sz. ábra:



Forrás: KTI, szerkesztette: Roadtech (ÚMFT KÖZOP:33)

Ezt a megállapítást támasztják alá a szerb-magyar határforgalomról közölt legfrissebb statisztikai adatok is. Ezekből az derül ki, hogy a 2010. év folyamán a határszakaszt mindösszesen (2, 1 millió személygépkocsival és 65.000 autóbusszal) 7,8 millió személy, ill. (350.000 tgk-ban 7,0 + 150.000 vasúti rakományban 6,0 = összesen) 13,0 millió t/év áru lépte át. A településeken belüli és a térség települései közötti személy- és áruforgalom igen durván becsülhető. A dél-magyarországi térségrészben kb. 0,6 millió utas km/év és 0,8+3,6 millió t/év, az északvajdasági térségrészben pedig kb. 0,4 millió utaskm/év és 0,5+1,8 millió t/év, mindösszesen a határrégió területén $\mathrm{kb}$. 1 millió utas $\mathrm{km} / \mathrm{e} v$ és 6,7 millió t/év nagyságrendü lehet. (Megközelítőleg 700 km/lakos/év, és kb. 900 t/lakos/év belső fogyasztási, ill. kb. 3 t/ha a térségből elszállításra kerülő mezőgazdasági terméktöbblettel számolva). Tehát a belső forgalom a határon átlépő és egyértelműen távolsági tranzitforgalomnak tekinthető utas- és áruforgalomnak mindössze alig $50 \%$-a (Sefcsich, 1997). 


\section{Perspektívák}

- Az elkövetkező évtizedek igényeit kiszolgálni hivatott, már folyamatban lévő közlekedési infrastruktúraépítések és az utas- és áruforgalmat ellátó, óriási erőforrások felett gazdálkodó globalista „húzó-,, háttér - ágazatok (gépjárműipar, energiagazdaság, logisztika) - az utóbbi évtized folyamán megtapasztalt súlyos gazdasági krízis ellenére és abból (úgy tünik) konzekvenciákat nem levonva rövidtávon ugyan még továbbra is igyekeznek fenntartani a jelenlegi közlekedési struktúrákat.

- A „fejlett” világ politikai vezetése azonban már mélyreható strukturális átrendeződéseket tervez és kezdeményez ezen a területen is. A vonatkozó EU irányelvekkel összhangban, már a magyarországi ÚSzT (Új Széchenyi Terv) is azzal számol, hogy 2020-ig a közúti közlekedés legfeljebb 67 \%-ra esik vissza, míg az energiatakarékosabb és környezetkímélöbb vasúti 20\%-ra, a vízi közlekedés pedig 8\%-ra növekszik.

- Köztudott azonban, hogy az így megfogalmazott fejlesztési célok/irányelvek csupán három döntő fontosságú eszköz bevetésével lesznek/lehetnek megvalósíthatók:

- olyan óriási vagyonértékü és kontinentális léptékü, előkészítő infrastruktúraberuházásokat kell viszonylag gyorsan (10-15 éven belül) megvalósítani a vasúti és a vízi közlekedés müszaki és logisztikai korszerüsítése területén, amelyek biztosítani tudják a közúti utas-szállítás kívánt kényelmi szintjét, ill. az áruszállításoknak a kísért közúti szállítmányokkal versenyképes hatékonyságát;

- olyan nagyhatékonyságú globális közlekedési és áruszállítási müszaki és logisztikai hálózati struktúrát kell kiépíteni és müködtetni, amely a minimumra csökkenti a „0-sebességü” átrakodási és átmeneti raktározási időket (egységrakományok, bimodális Ro-La és Ro-Ro terminálok, valamint multimodális konténeres és cserefelépítményes szállítási technikák és átrakóállomások), ill. csomópontjain (áruforgalmi termináljain) optimális módon oldja fel a távolsági és a kisközösségi áruszállítás között feszülő rakomány-képzési/lebontási és kézbesítési problémákat; és

- biztosítani kell a közúti, vasúti és vízi szállítás minden tekintetben egyenrangú piaci versenyhelyzetét, teljesítményarányosan terhelve meg azokat az őket kísérő infrastruktúra-beruházások és környezetvédelmi ráfordítások valós terheivel, 
- mert csupán akkor és ilyen körülmények között lesz majd megengedhető és elvárható, hogy a közlekedési ágazatban is szabadon érvényesüljenek a piaci versenyszabályok, kényszerüen elvezetve a világgazdaságot addig a töréspontig, amelyben - a fogyó és dráguló energiahordozók terhei alatt - már valóban értelmetlenné válik majd a jelenlegi tékozló közúti majoritású közlekedési és áruszállítási struktúra.

- Ezeknek a globális folyamatoknak a régió arculatát formáló hatásai viszonylag jól behatárolhatók és egyértelműen betekinthetőek, ezért - a kívülről érkező kihívásokra adott válaszként - a régió fejlesztési stratégiája is szabatosan megfogalmazható egy, a térség specifikumaira vonatkoztatott fejlesztési operatív program keretében, melynek fontosabb vezérgondolatai (a teljes igénye nélkül) a következők:

- Ki kell építeni és folyamatosan javítani a határrégió lakosságának belső és határon átnyúló mobilitását.

- Ki kell építeni és folyamatosan erősíteni a határrégió lakosságában a regionális összetartozás identitásképét.

- Tudatosítani kell, hogy a regionális kohézió és összetartás a térség egyedül racionális viselkedésformája és válasza a jövő megpróbáltatásaira és kihívásaira, hiszen ellenkező esetben a gyakorlatilag azonos erőforrásokból és célpiacokból kényszerűen eredő belső versenyhelyzet mindenképpen hátrányos lenne a térség egésze számára.

- Ki kell építeni a határrégiót a környezetétől megkülönböztető identitást, biztosítani kell a régió belső és határon átnyúló kohézióját. Igen fontos a régió délmagyarországi és északvajdasági kistérségeinek Szeged- és Szabadka-központú belső integrációja, valamint a Szeged/Szabadka ikervárosi összefonódás megteremtése.

- A regionális összetartozást nem csak, mint gazdasági kényszert kell megélni, hanem szakmai, közoktatási/kulturális, turisztikai, egészség- és környezetvédelmi, energiagazdálkodási és gazdasági, közigazgatási és biztonságtechnikai stb. együttműködési tartalmakkal kell feltölteni és gazdagítani. 
- Intézményesíteni kell a régión belüli civil és gazdasági és együttműködések (mindenek előtt a KKV - struktúrák) mindennapos gyakorlatát, ahhoz eszközöket, szervezést és támogatási forrásokat rendelve.

- Minden lehetséges eszközzel biztosítani kell a régión belüli mobilitás alapvető feltételeit (közúthálózat, közületi közlekedési útvonalak kiterjesztése a perifériák felé, új lokális határátkelőhelyek megnyitása, stb.).

- Támogatni kell minden lehetséges eszközzel a régió belső közúti, vasúti és vízi infrastruktúra- és logisztikai rendszereinek felújítását/fejlesztését (a szegedi vasúti/közúti híd újjáépítését, a Temesvár - Szabadka - Szeged - Fiume és a Szabadka - Szeged - Budapest vasúti korridorok felújítását, ill. a Duna teljes körű és a Tisza Szekszárdig kiterjesztett hajózhatóságát és a Szegedi mederkikötő felújítását).

- Támogatni kell a szeged környéki bi- és multimodális áruterminálok logisztikai központokká fejlesztését, valamint a szabadkai szabad vámövezet és a régió területén működő/tervezett KKV - inkubátorközpontok és közös KF - központok fejlesztését és müködését.

\section{Következtetések}

1. A fenti elemzés részben igen megbízhatatlan adatokra, sőt esetenként becslésekre (is) támaszkodik, nagyságrendjében mindenképpen a valóságot igazolja, vagyis azt a tényt, hogy a határrégió egészére vonatkoztatva sajnálatos módon, jól kitapinthatóan, sőt egyértelmúen érvényesülni látszanak az ,alagútként működő" nagy forgalmú tranzitkorridor igen negatív hatása. A növekvő intenzitású, meghatározó mértékben tranzit jellegü átmenő forgalom környezetterhelő és negatív társadalomlélektani hatásait ugyanis nem (vagy csak jelentéktelen mértékben) kompenzálják korridor-nyomvonal mentén kialakuló fejlődőképes kontaktzónák és területsávok pozitív gazdaságélénkítő hatásai.

2. Az elemzés egyértelmüen utal arra a tényre is, hogy (mind a régió szomszédos települései, mind pedig a határon túli és a szomszédos térségek viszonylatában) meglepően alacsony a határrégió lakossági mobilitása. 
3. A ,belső” áruforgalom viszonylag csekély intenzitása arra utal, hogy szinte nyomai sem érzékelhetők a térség regionális/hálózati társadalmi/kulturális és gazdasági integrációjának.

4. A lakossági mobilitás-hiány részben éppen a regionális integráció hiányára utal, hiszen a térség természetes központjai (Szeged és Szabadka) nem tudják (nem képesek?) megfelelően ellátni térségfejlesztő hálózati csomóponti szerepüket hiszen a kényszerű (közhivatali, közoktatási és egészségügyi jellegű) integratív elemek mellett szinte teljességgel hiányoznak-leépültek a korábban még létezett gazdasági visszacsatolások (pl. szinte megszünt a központi települések és a perifériák közötti tömeges ,ingázás”).

5. A teljesség igénye nélkül, ankétrendszerü felmérés keretében vizsgált „határon átnyúló" mobilitás elgondolkodtató eredményeket mutatott.

6. A magyarországi lakosság közel $65 \%$-a, és a vajdaságiak 55\%-a az elmúlt 10 év folyamán nem utazott „,a határon túlra”, és a megkérdezettek ezt egybehangzóan „a nehéz gazdasági körülményekkel”, ill. a rossz és/vagy müködésképtelen (vasúti és autóbusz-) közületi közlekedéssel, ill. az elégtelen számú határátkelő gyakori tranzittúlterheltségéből eredő kényelmetlenségekkel indokolták.

7. Szimptomatikus jelenség az is, hogy a „határon túlra utazó” megkérdezettek döntő többsége nyilatkozott úgy, hogy utazásának célja mindenekelőtt (vagy csak) vásárlás volt és azt csupán (jellemzően a vajdasági) utazók kisebb része egészítette ki wellness és gasztronómiai tartalmakkal. Konvencionális (korábban megszokott, sőt jellemző) kulturális/turisztikai, oktatási/tudományos és/vagy gazdasági kapcsolatok ápolása - ebben a kontextusban - csupán elvétve jelent meg.

8. A felvázolt perspektívák hatalmas anyagi és szellemi erőfeszítést kíván nem csak a szűken behatárolt határ- menti régióktól, hanem Magyarországtól, Szerbiától, de az európai Uniótól is.

\section{Irodalom}

Ada község fejlesztési stratégiája, 205-2008-2012, Harmadik változat, 2006.

A magyar úthálózatot igénybe vevő nemzetközi tehergépjármü-forgalom útdíjérzékenységének elemzése, Traffikon, Budapest, 2008.

BALOGH T.: A Fiume (Rijeka) Constanta vasúti kapcsolat fejlesztése, transzbalkáni vasútvonal kialakítása, EÖKK, Budapest, 2010.

Befektetési kézikönyv, Regionalni centar d.o.o. „Most - Híd” Térségfejlesztési Központ Kft., Szabadka

Dél-Alföldi operatív program, MK Kormány, 2007. 
DKMT eurorégió stratégiája, MTA RKK, Alföldi Tudományos Intézet, 1997

Dunavska strategija EU i Srbija - Plovidba i prevoz (Az EU Duna-stratégiája - hajózás és áruszállítás), RIS, Belgrád, 2010.

ERDŐSI F.a: A Balkán közlekedése és a politika (prezentáció), 2006. www.balkancenter.hu/pdf/elemzes/ppt/erdosi06.ppt (letöltés dátuma: 2010.12.03.)

ERDÖSI F.b: A Balkán közlekedésének főbb földrajzi jellemzői, Balkán füzetek No. 3, PTE TTK FI Kelet-Mediterrán és Balkán Tanulmányok Központja, Pécs, 2005

ERDÖSI F.c: Transzeirópai közlekedési tengelyek fejlesztési iránya és hatása a Balkán térszerkezetére (A bővített változat vázlata), MTA Regionális Kutatások Központja. Pécs

EU közlekedési statisztika, Eurostat, Brüsszel, 2010. szeptember

FLEISCHER T.: A gyorsforgalmi úthálózat és a környezet, Közlekedéstudományi Szemle, 1994.

GOSPIĆ N., BOJOVIĆ N., MAČVANSKI D., STOJIČIĆ-ĐERIĆ Z., MILJANOVIĆ LJ.: Procena ekonomskih efekata integracije Srbije u EU za oblast saobraćaja (Szerbia EU-integrációja gazdasági hatásainak értékelése a közlekedési ágazatban), FEFA, Beograd, 2010.

HUSZKA B., BAKÓ T.: Észak-Vajdaság magyar többségű községeinek gazdasága Mühelytanulmány, EÖKK, Budapest, 2007.

Jelentés a vajdasági magyarok helyzetéröl, HTMH Budapest, 2006.

Magyarkanizsa község fejlesztési terve 2006-2010, 2006.

NAGY I. (szerk.): A Kárpát-medence régiói - Vajdaság, Magyar Tudományos Akadémia,

Regionális Kutatások, Központi Dialóg Campus Kiadó, Pécs-Budapest, 2007.

Opštine u Srbiji, 2010

Opština Odžaci http://odzaci.opstinesrbije.com/index.php?menu=9\&submenu=2008 15 (letöltés dátuma: 2010.12.03.)

PÁL Á., PÁL V.: A határ menti fekvés hatása a szegedi kereskedelem térbeliségére OTKA kutatás, 2006.

Program razvoja opštine Mali Iiđoš 2008-2012, Republički zavod za razvoj, Beograd, 2008.

Rečni saobraćaj - Master plan za vodni saobraćaj (Folyami közlekedés - Vízi közlekedési vezérterv), Vlada Republike Srbije, Beograd, 2010.

Regionalna razvojna strategija Banat 2009-2013

Robna razmena AP Vojvodine sa inostranstvom za 2010. godinu (Vajdaság AT árucseréje a külfölddel 2010-ben), Republički zavod za statistiku, Beograd, 2010.

Šanse železnice su u Koridoru 4 (A vasút kitörési lehetőségét a 4. korridor biztosítja), Blic online, 2010.

SEFCSICH GY.a: Az észak-vajdasági régió gazdasága, Európai tükör, 2007/11

SEFCSICH GY.b: Ekonomska efektivnost rada zimske službe (radni tekst), Subotica, 1997

SEFCSICH GY.c: Északvajdasági regionális fejlesztési koncepció - Infrastruktúra és szolgáltatások, RTT-résztanulmány, Szabadka, 2006. szeptember

SEFCSICH GY.d: Ipar és energiagazdaság (Résztanulmány), RTT-projekt, (Északvajdasági) regionális fejlesztési koncepció: C.2, Szeged, 2006.

SEFCSICH GY., SOMOGYI S., MARÁCI L.: Mogućnost uspostavljanja koncepta održivog razvoja urbane sredine i gravitacione poleđine grada Subotice, Most-Híd, Regionalni razvojni centar d.o.o. Subotica, 2008

SZAKÁLI I. L.: A magyar-szerb kapcsolatok helye és szerepe a térségi szintü gazdasági folyamatokban, Nemzetgazdasági Minisztérium, 2011. január

Statistički godišnjak Srbije za 2010. godinu (Szerbia 2010. évi statisztikai évkönyve), Republički zavod za statistiku, 2011. március

Strategija ekonomskog razvoja opštine Kikinda, 2007 
Strategija lokalnog održivog razvoja opštine Sombor, 2007

Strategija održivog razvoja opštine Apatin 2009-2019

Strategija održivog razvoja opštine Kula, 2008

Strategija razvoja železničkog, drumskog, vodnog, vazdušnog i intermodalnog transporta u Republici Srbiji od 2008. do 2015. godine

Strategija regionalnog razvoja Republike Srbije za period od 2007 do 2012 godine Szabadka község fejlesztési stratégiája 2007-2011, 2007.

Topolya község gazdasági fejlesztésének stratégiai irányelvei

VERBÓCZKY J.: A magyarországi kombinált árufuvarozásról, GKM, Budapest

Zenta község fejlesztési terve 2007-2013 